\title{
Analisis proksimat tepung daging buah labu kuning (Cucurbita moschata)
}

\section{Dokri Gumolung*}

Kimia FMIPA, Universitas Negeri Manado, Tondano, 95619, Indonesia

\begin{tabular}{l} 
IN F O A R T I K E L \\
\hline Diterima 3 April 2019 \\
Disetujui 29 April 2019 \\
\hline Key word: \\
Pumpkin Meat, protein, fat, \\
fiber, carbohydrates, water, ash \\
\hline Kata kunci: \\
Daging Labu Kuning, \\
protein, lemak, serat, \\
karbohidrat, air, abu
\end{tabular}

*e-mail:

dokrigumolung@gmail.com

*Telp:

085396672121

\begin{abstract}
A BSTRACT
The purpose of this study was to measure the levels of protein, fat, fiber, carbohydrates, water and ash, in meat flour from pumpkin fruit. Pumpkin is a nutrient-rich food needed by humans. Consumer knowledge of the nutritional content of pumpkin fruit which is still minimal makes pumpkin fruit categorized as a minor food commodity. This research was carried out using laboratory analysis methods with the following stages, determination and sampling, sample preparation, protein content analysis of the gunning method, fat content with the soxhlet method, method fiber content SNI 01-2891-1992, carbohydrate content and water content and ash by oven drying method. The results showed that pumpkin from yellow pumpkin had a protein content of $4.28 \%, 0.18 \%$ fat, $0.93 \%$ fiber, $83.18 \%$ carbohydrate, $6.75 \%$ water and ash $4.68 \%$. The results of this study concluded that pumpkin fruit flour can be made as food fortification ingredients to increase the nutritional value of food ingredients.
\end{abstract}

\section{A B S T R A K}

Tujuan penelitian ini adalah untuk mengukur kadar protein, lemak, serat, karbohidrat, air dan abu, pada tepung daging dari buah labu kuning. Labu kuning merupakan bahan pangan yang kaya zat gizi yang dibutuhkan oleh manusia. Pengetahuan konsumen akan kandungan zat gizi pada daging buah labu kuning yang masih minim menjadikan buah labu kuning dikategorikan sebagai komoditas pangan minor. Penelitian ini dilaksanakan dengan menggunakan metode analisis laboratorium dengan tahapan-tahapan sebagai berikut, penentuan dan pengambilan sampel, preparasi sampel, analisis kadar protein metode gunning, kadar lemak dengan metode soxhlet, kadar serat Metode SNI 01-2891-1992, kadar karbohidrat dan kadar air dan abu dengan metode oven pengeringan. Hasil penelitian menunjukkan bahwa tepung daging dari buah labu kuning memiliki kadar protein $4.28 \%$, lemak $0.18 \%$, serat $0.93 \%$, karbohidrat $83.18 \%$, air $6.75 \%$ dan abu $4,68 \%$. Hasil penelitian dapat disimpulkan bahwa tepung daging buah labu kuning dapat dijadikan sebagai bahan fortifikasi pangan untuk meningkatkan nilai gizi bahan makanan.

\section{Pendahuluan}

Labu kuning atau waluh (Cucurbita moschata), termasuk bahan baku pengolahan pangan yang sering dimanfaatkan sebagai bahan tambahan dalam pengolahan makanan tradisional masyarakat Sulawesi Utara. Walaupun pemanfaatan labu kuning sebagai komoditas pangan minor sudah berlangsung ratusan tahun, namun pengenalan secara ilmiah terhadap kandungan zat gizi serta senyawa bioaktif lainnya masih sangat kurang bagi masyarakat produsen bahan makanan dan juga masyarakat konsumen. Kurangnya pemahaman kandungan zat gizi dalam bahan baku makanan seperti buah labu kuning disebabkan oleh karena minimnya informasi ilmiah melalui berbagai penelitian yang didapatkan oleh masyarakat produsen maupun konsumen bahan makanan dengan tambahan buah labu kuning. Pengetahuan yang benar dan 
mendalam terhadap kandungan gizi dalam bahan baku pengolahan makanan akan berdampak kepada pemanfataan yang lebih luas lagi dan variatif bagi bahan baku makanan yang dimaksud. Buah labu kuning dapat digunakan untuk pelbagai jenis makanan, daunnya berfungsi sebagai sayur, air buahnya berguna sebagai penawar racun binatang berbisa, sementara bijinya menjadi obat cacing pita [1]. Jonjot labu kuning telah diteliti memiliki kandungan fenolik dan beta karoten yang tinggi $[2,3]$. Penelitian sebelumnya juga mengenai tepung jonjot labu kuning disumpulkan bahwa tepung jonjot dapat dimanfaatkan sebagai bahan fortifikasi pangan untuk meningkatkan gizi [4]. Dengan memperhatikan potensi pengolahan daging buah labuh kuning sebagai bahan pangan masih kurang dipahami dengan baik perihal kandungan zat gizi oleh konsumen, maka selayaknyalah dilakukan penelitian tentang kandungan zat gizi daging buah labu kuning.

\section{Bahan dan Metode}

Bahan utama yang digunakan dalam penelitian ini adalah buah labu kuning umur panen 3-4 bulan, yang diperoleh dari Daerah Modoinding Minahasa Selatan Propinsi Sulawesi Utara. Bagian buah yang digunakan untuk penelitian ini adalah daging yang sudah biasa dikonsumsi.. Bahan kimia yang digunakan adalah petroleum eter, etanol, natrium hidroksida, asam sulfat, natrium karbonat. Alat-alat oven pengeringan, tanur, satu soklet.

\section{Preparasi Sampel}

Buah labu kuning dibersihkan/dicuci dengan air, selanjutnya dipisahkan bagian kulit, daging, biji dan jonjot. Bagian daging buah yang sudah dipisahkan kemudian dikeringkan dengan oven pada suhu $60-70{ }^{\circ} \mathrm{C}$, setelah kering dihaluskan dengan menggunakan blender, selanjutnya diayak sampai diperoleh partikel dengan ukuran 60 mesh dan diperoleh tepung jonjot buah labu kuning.

\section{Analisis Proksimat}

Tepung jonjot dianalisis kadar protein metode gunning, kadar lemak dengan metode soxhlet [5], kadar serat metode SNI 01-28911992 , kadar karbohidrat dan kadar air dengan metode oven pengeringan dan kadar abu dengan metode tanur pembakar [6].

\section{Hasil dan Pembahasan}

\section{Analisis Proksimat}

Tepung daging labu kuning yang diperoleh, telah dilakukan pengukuran kandungan gizi, dan hasil analisis dapat dilihat pada Tabel 1 di bawah ini.

Tabel 1. Analisis Proksimat Daging Labu

\begin{tabular}{cc}
\multicolumn{2}{c}{ Kuning } \\
\cline { 2 - 2 } Zat Gizi & Kadar $(\%)$ \\
\cline { 2 - 2 } & Daging \\
\hline Protein & 4,28 \\
Lemak & 0,18 \\
Serat & 0,93 \\
Karbohidrat & 83,18 \\
Kadar Air & 6,75 \\
Kadar Abu & 4,68 \\
\hline
\end{tabular}

Protein

Kadar protein tepung daging dalam buah labu kuning yaitu 4,28\% dibandingkan dengan data yang diungkapkan oleh Kamsiati, dimana kadar protein tepung labu kuning sebesar 3,74\% [7]. Hal ini dapat disimpulkan bahwa kandungan protein pada daging, buah labu kuning dalam penelitian ini lebih tinggi kandungannya dibandingkan dengan penelitian sebelumnya.

Protein merupakan suatu zat makanan yang amat penting bagi tubuh, karena zat ini di samping berfungsi sebagai bahan bakar dalam tubuh juga berfungsi sebagai zat pembangun dan pengatur. Sebagai zat pembangun protein merupakan bahan pembentuk jaringanjaringan baru yang selalu terjadi dalam tubuh. Semakin tinggi kadar protein pada bahan makanan tersebut maka kualitas bahan makanan tersebut akan semakin bagus nilai gizinya bagi manusia. Fungsi utama protein bagi tubuh ialah untuk membentuk jaringan baru dan mempertahankan jaringan yang telah ada. Protein dapat juga di gunakan untuk bahan bakar apabila keperluan energi tunbuh tidak terpenuhi oleh karbohidrat dan lemak. 
Protein mengatur keseimbangan cairan dalam jaringan dan pembuluh darah, yaitu dengan menimbulkan tekanan osmotik koloid yang dapat menarik cairan dari jaringan ke dalam pembuluh darah. Sifat atmosfer protein yang dapat bereaksi dengan asam dan basa, dapat mengatur keseimbangan asam-basa dalam tubuh. Protein dalam tubuh manusia dalam sel jaringan bertindak sebagai bahan membran sel, dapat membentuk jaringan pengikat misalnya kolagen dan elastin, serta membentuk protein yang inert seperti rambut dan kuku. Disamping itu protein yang bekerja sebagai enzim, bertindak sebagai plasma (albumin), membentuk antibodi, membentuk komplek dengan molekul lain serta dapat bertindak sebagai bagian sel yang bergerak.

\section{Kadar Lemak}

Penetapan kadar lemak pada buah labu kuning tersebut dengan metode soxhlet ini dilakukan dengan cara mengeluarkan lemak dari sampel dengan pelarut petroleum eter. Setelah diekstraksi, maka pelarut diuapkan dalam wadah pada suhu $100{ }^{\circ} \mathrm{C}$ kemudian ditimbang sampai berat konstan. Berat residu dinyatakan sebagai berat lemak. Hasil pengukuran yang ditampilkan pada Tabel 1, diperoleh kadar lemak yang tinggi pada daging $0,18 \%$, dibandingkan dengan data yang diungkapkan oleh Kamsiati (2010), dimana kadar lemak tepung labu kuning sebesar 1,34\% [7]. Hal ini dapat disimpulkan bahwa kadar lemak pada daging lebih rendah dibandingkan dengan penelitian sebelumnya.

Kadar Serat

Berdasarkan hasil pengujian kadar serat pada tepung daging sebesar 0,93\%, dibandingkan dengan data yang diungkapkan oleh Kamsiati (2010), dimana kadar serat tepung labu kuning sebesar 2,90\%, maka kadar serat hasil penelitian, lebih kecil dibandingkan dengan serat buah labu kuning hasil penelitian sebelumnya [7].

Serat kasar terdiri dari selulosa dengan sedikit lignin dan pentosan. Serat merupakan komponen bagi jaringan tanaman yang tahan terhadap proses hidrolisis terhadap enzim dalam lambung dan usus kecil. Serat adalah suatu karbohidrat kompleks di dalam bahan pangan yang tidak dapat dicerna oleh enzimenzim pencernaan manusia, sehingga dapat mencapai usus besar dan dicerna oleh bakteri probiotik. Hal ini menjadikan serat bersifat prebiotik. Konsumsi serat yang cukup setiap harinya dapat mengurangi resiko terkena kanker kolon karena mempersingkat waktu transit makanan. Serat juga menjaga kesehatan mikroflora usus, mencegah hipertensi dan penyakit batu empedu, serta mencegah obesitas.

\section{Kadar Karbohidrat}

Karbohidrat merupakan sumber kalori utama bagi manusia. Kadar karbohidrat yang terdeteksi pada tepung daging buah labu kuning sebesar $83,18 \%$. Hal ini menunjukan bahwa kandungan karbohidrat pada bagian buah labu kuning dalam penelitian ini dibandingkan dengan kadar karbohidrat tepung labu kuning menurut penelitian sebelumnya yakni $77,65 \%$. maka kandungan karbohidrat pada tepung daging labu kuning dalam penelitian ini lebih tinggi $5.56 \%[7,8]$.

\section{Kadar air}

Kadar air juga salah satu karakteristik yang sangat penting pada bahan pangan, karena air dapat mempengaruhi penampakan, tekstur, dan citarasa pada bahan pangan. Hasil pengujian diperoleh kadar air pada daging 6,75\%, dibandingkan dengan kadar air tepung labu kuning menurut Widowati et al., 2001 yakni 11,14\%. Perbandingan tersebut di atas disimpulkan kadar air pada tepung daging buah labuh kuning lebih rendah dari kadar air dalam penelitian sebelumnya. Kadar air dalam bahan pangan ikut menentukan kesegaran dan daya awet bahan pangan tersebut, kadar air yang tinggi mengakibatkan mudahnya bakteri, kapang, dan khamir untuk berkembang biak, sehingga akan terjadi perubahan pada bahan pangan.

\section{Kadar Abu}

Kadar abu mengacu pada residu inorganik yang tersisa setelah oksidasi sempurna dari komponen organik bahan pangan. Nilai kadar abu hasil analisis pada daging buah labu kuning sebesar 4,68\%, dibandingkan dengan kadar abu tepung labu 
kuning pada penelitiian sebelumnya yakni $5,89 \%$. Perbandingan tersebut di atas disimpulkan kadar abu pada tepung daging buah labuh kuning lebih rendah dari kadar abu dalam penelitian sebelumnya [8].

\section{Kesimpulan}

Hasil penelitian menunjukkan bahwa tepung daging dari buah labu kuning memiliki kadar protein $4.28 \%$, lemak $0.18 \%$, serat $0.93 \%$, karbohidrat $83.18 \%$, air $6.75 \%$ dan Abu 4,68 $\%$. Hasil penelitian dapat disimpulkan bahwa tepung jonjot buah labuh kuning dapat dijadikan sebagai bahan fortifikasi pangan untuk meningkatkan nilai gizi.

\section{Daftar Pustaka}

1. Astawan, M., Labu kuning penawar racun dan cacing pita yang kaya antioksidan. IPB. Bogor.(http://www. gizi. net/cgibin/berita/fullnews). Diakses: 2004.

2. Gumolung, D., Analisis beta karoten dari ekstrak jonjot buah labu kuning (Cucurbita moschata). Fullerene Journal of Chemistry 2017, 2, (2), 69-71.

3. Gumolung, D., Analisis kandungan total fenolik pada jonjot buah labu kuning (cucurbita moschata). Fullerene Journal of Chemistry 2018, 3, (1), 1-4.

4. Gumolung, D.; Mamuaja, M. N., Analisis Proksimat Tepung Jonjot Buah Labu Kuning. Fullerene Journal of Chemistry 2018, $3,(2), 40-43$.

5. Sudarmadji, S.; Suhardi; Haryono, B., Analisa bahan makanan dan pertanian. Liberty Yogyakarta: 1989.

6. Indonesia, S. N., Indonesia 01-2891-1992. Uji makanan dan minuman. Badan Standardisasi Nasional 1992.

7. Kamsiati, E., Labu Kuning untuk Bahan Fortifikasi Vitamin A. In Badan Penelitian Pengengembangan Pertanian Kalimantan Tengah, KalTeng, B., Ed. Badan Penelitian Pengengembangan Pertanian Kalimantan Tengah: Kalimantan Tengah, 2010.

8. Widowati, S.; Damardjati, D. S., Menggali Sumberdaya Pangan Lokal dalam Rangka Ketahanan Pangan. Majalah PANGAN no 2001, 36. 